\title{
PENGARUH RECIPROCAL TEACHING DAN PROBLEM BASED LEARNING TERHADAP KEMAMPUAN BERPIKIR KRITIS PESERTA DIDIK SMA PADA MATERI SISTEM REPRODUKSI
}

\section{The Effect of Reciprocal Teaching and Problem Based Learning to The Critical Thinking of Senior High School Students in Reproduction System Material}

\author{
Hani Anggraeni' ${ }^{1}$, Sri Rahayu ${ }^{2}$, Rusdi ${ }^{1}$, Ilmi Zajuli Ichsan ${ }^{1}$, \\ ${ }_{1}$ Program Studi Pendidikan Biologi, FMIPA, Universitas Negeri Jakarta \\ Jakarta, Indonesia \\ ${ }^{2}$ Program Studi Biologi, FMIPA, Universitas Negeri Jakarta \\ Corresponding author: srirahayu@unj.ac.id
}

\begin{abstract}
Student center learning leads to changing teacher roles. Learners are required to have HOTS, one of the capabilities including HOTS is critical thinking ability. The purpose of this research is to know the influence of learning model RT and PBL to critical thinking ability of high school. This research was conducted on April-June 2017 at SMAN 102 Jakarta in class XI with 99 sample of students. This research is quasi experiment with Post-Test Only Control Group Design. The results of ANOVA test one way and critical data is rejected $\mathrm{HO}$, meaning there is a difference in the average ability of critical thinking learners. The involvement of learners in PBL learning can help in developing critical thinking skills, because PBL involves the ability of learners to search and investigate logically, critically and analytically so that they can formulate their own problem solving. Conclusion of this research, there is the influence of learning RT and PBL on the critical thinking skills of high school students on the material reproduction system.
\end{abstract}

Keywords: critical thinking skills, problem based learning, reciprocal teaching 


\section{PENDAHULUAN}

Peran guru saat ini mengalami pergeseran. Guru bukan hanya mendidik dan mentransfer ilmu pengetahuan. Pada kurikulum 2013, dituliskan bahwa peserta didik dituntut untuk dapat memiliki kemampuan berpikir tingkat tinggi (Higher Order Thinking Skills/HOTS). Salah satu yang termasuk dalam HOTS adalah kemampuan berpikir kritis. Berpikir kritis merupakan salah satu jenis berpikir yang konvergen, yaitu menuju ke satu titik. Menurut Hasruddin (2009) kemampuan berfikir kritis harus dimiliki peserta didik agar pembelajaran menjadi lebih baik.

Kemampuan berpikir kritis dapat ditingkatkan melalui pembelajaran kooperatif. Hal ini didukung oleh pernyataan Arends (2008) yang berpendapat bahwa pembelajaran berkelompok memiliki banyak kelebihan salah satunya melatih kerjasama dan kemampuan berfikir kritis. Guru harus menyajikan pembelajaran yang menarik dan menyenangkan bagi peserta didik agar tercapainya suatu kompetensi dan profesionalisme guru dalam kegiatan pembelajaran (Sunilawati, 2013). Model pembelajaran yang diduga dapat meningkatkan kemampuan berpikir kritis dapat adalah model pembelajaran Reciprocal Teaching, Problem Based Learning (PBL) dan Student Achievement Teams Divisions (STAD).

Berdasarkan kegiatan utama model pembelajaran Reciprocal Teaching dapat meningkatkan kemampuan berpikir kritis peserta didik. Hal ini sesuai dengan pendapat Wicaksono (2014) bahwa Reciprocal Teaching dapat mengakomodasi peserta didik untuk melatihkan keterampilan metakognitif dan berpikir kritisnya yang nantinya dapat mempengaruhi hasil belajar kognitif peserta didik tersebut. Menurut Abdullah (2014) menyebutkan bahwa pembelajaran PBL dapat meningkatkan kemampuan berfikir kritis, menumbuhkan inisiatif dalam belajar atau bekerja, menumbuhkan motivasi untuk belajar dan dapat mengembangkan hubungan interpersonal dalam bekerja kelompok. Model pembelajaran kooperatif tipe STAD merupakan tipe kooperatif yang menekankan pada adanya aktivitas dan interaksi diantara peserta didik untuk saling memotivasi dan 
saling membantu dalam menguasai materi pelajaran guna mencapai prestasi yang maksimal (Isjoni, 2009)

Pada jenjang SMA materi yang dianggap sulit dipahami dan kompleks dalam meningkatkan kemampuan berpikir kritis peserta didik yaitu materi sistem reproduksi. Hal ini didukung oleh pernyataan Fitriani (2014) yang menyatakan bahwa sistem reproduksi merupakan salah satu materi yan kompleks dan sulit dipahami oleh peserta didik karena sistem reproduksi bukan hanya sekedar materi tetapi materi ini merupakan pendidikan seks yang erat kaitannya dengan kehidupan peserta didik seharhari sehingga dibutuhkan kemampuan berpikir tingkat tinggi.

Kemampuan Berpikir Kritis adalah bersifat tidak mudah percaya, selalu berusaha menemukan kesalahan atau kekeliruan, dan tajam dalam penganalisaan (KBBI, 2005). Berpikir adalah memanipulasi atau mengelola dan mentransformasikan informasi dalam memori (Santrock, 2008). Menurut Ennis (1996), berpikir kritis adalah suatu proses penggunaan kemampuan berpikir secara efektif yang dapat membantu seseorang untuk membuat, mengevaluasi serta mengambil keputusan tentang apa yang diyakini atau dilakukan. Sementara itu, proses berpikir kompleks meliputi pemecahan masalah, pengambilan keputusan, berpikir kreatif dan berpikir kritis. Menurut Fisher (2009), berpikir kritis merupakan interpretasi dan evaluasi yang terampil serta aktif terhadap observasi dan komunikasi, terhadap informasi dan augmentasi.

Berpikir kritis menuntut upaya keras untuk memeriksa keyakinan atau asumsi berdasarkan bukti pendukung dan kesimpulan-kesimpulan lanjutan yang ditimbulkannya. Moore (2009), memberikan ilustrasi bahwa berpikir kritis lebih kompleks dari berpikir biasa karena berpikir kritis berbasis pada standar objektivitas dan konsistensi. Selain itu, Moore (2009), juga mengatakan bahwa, berpikir kritis dapat dikembangkan sejak dini dan tidak tergantung pada tingkat kecerdasan intelektual seseorang. Menurut Masek (2011), pemikiran kritis dapat diukur berdasarkan kemampuan peserta didik untuk fokus dan memperjelas solusi, menganalisa, memahami, dan menyimpulkan dengan penilaian pengaturan diri dan anggapan. Karena itu, mengajarkan kemampuan berpikir kognitif tingkat 
tinggi seperti berpikir kritis selalu menjadi tujuan akhir dari pendidikan sebagaimana tertuang dalam kurikulum pendidikan nasional.

Pada model pembelajaran RT guru lebih berperan sebagai fasilitator yang memberi kemudahan, dan pembimbing yang melakukan scaffolding. Scaffolding merupakan suatu bimbingan yang diberikan oleh orang yang lebih tahu kepada orang yang kurang tahu (guru pada peserta didik atau peserta didik yang paham pada yang kurang paham) (Ibrahim, 2008).

Menurut Pannen (dalam Suyitno, 2004) tujuan dari pembelajaran Reciprocal Teaching ini diharapkan peserta didik dapat mengembangkan keinginan belajar mandiri. Selain itu, peserta didik memiliki kemampuan untuk mengembangkan pengetahuannya sendiri. Reciprocal Teaching merupakan pembelajaran yang dapat membantu peserta didik dalam berpikir dan memahami suatu teks sebelum, saat, dan setelah membacanya (Doolittle, 2006).

Menurut (Doolittle, 2006) Reciprocal Teaching memiliki empat kegiatan utama, seperti berikut ini, summarizing (Meringkas) dalam kegiatan summarizing bertujuan untuk melatih peserta didik memahami inti dari teks bacaan. Question Generating (Membuat Pertanyaan) yang bertujuan untuk mengetahui pemahaman peserta didik terhadap teks bacaan dengan menggali informasi yang telah peserta didik miliki sebelumnya. Clarifying (Mengklarifikasi) yaitu merupakan strategi untuk peserta didik memahami kembali kata-kata yang belum jelas atau yang tidak mereka mengerti. Predicting (Memprediksi) yaitu merupakan gabungan antara pengetahuan awal peserta didik dengan pengetahuan baru yang didapat dari teks yang dibaca untuk membuat hipotesis.

Problem Based Learning (PBL) dikembangkan untuk pertama kali oleh Howard Barrows sekitar tahun 1970-an dalam pembelajaran ilmu medis di McMaster (Amir, 2013). Pembelajaran berbasis masalah sengaja dikembangkan untuk membantu peserta didik dalam mengembangkan kemampuan berpikir, memcahkan masalah, dan keterampilan intelektual (Afcariono, 2008). Model pembelajaran ini menyajikan suatu masalah nyata bagi peserta didik sebagai awal pembelajaran 
kemudian diselesaikan melalui penyelidikan dan diterapkan dengan menggunakan pendekatan pemecahan masalah. Hal ini didukung oleh pernyataan Sudarman (2007), PBL merupakan suatu metode pembelajaran yang menggunakan masalah dunia nyata sebagai suatu konteks bagi peserta didik untuk belajar tentang cara berpikir kritis dan keterampilan pemecahan masalah, serta untuk memeroleh pengetahuan dan konsep yang penting dari materi pelajaran.

Menurut Suyadi (2013), PBL merupakan pembelajaran kooperatif karena pada pembelajaran PBL menekankan belajar kooperatif dengan meyediakan cara untuk inquiry yang bersifat kolaboratif dan belajar. Dalam proses PBL, peserta didik belajar bahwa bekerja dalam tim dan kolaborasi itu penting untuk mengembangkan proses kognitif yang berguna untuk meneliti lingkungan, memahami permasalahan, mengambil dan menganalisis data penting dan mengelaborasi solusi. PBL memiliki gagasan bahwa pembelajaran dapat dicapai jika kegiatan pendidikan

Pada tugas atau permasalahan yang otentik, relevan, dan dipresentasikan dalam suatu konteks. Dalam model pembelajaran PBL ini, pemahaman, transfer pengetahuan, keterampilan berpikir tingkat tinggi, kemampuan pemecahan masalah, dan kemampuan komunikasi ilmiah merupakan dampak langsung pembelajaran (Afandi, 2012). Menurut Ibnu (2014), pengajaran berdasarkan masalah merupakan pendekatan yang efektif untuk pengajaran proses berpikir tingkat tinggi. Pembelajaran ini membantu peserta didik untuk memproses informasi yang sudah jadi dalam benaknya dan menyusun pengetahuan mereka sendiri tentang dunia sosial dan sekitarnya. Hal ini didukung pernyataan Afandi (2012), pembelajaran dengan model PBL secara signifikan dapat memengaruhi kemampuan berpikir kritis dan prestasi belajar.

Student Team Achievement Divisions (STAD) merupakan model pembelajaran kooperatif yang sederhana (Ibrahim, 2008). Dikatakan demikian, karena masih dekat kaitannya dengan pembelajaran konvesional. Hal ini didukung oleh pernyataan Majid (2013) yang mengatakan bahwa pembelajaran STAD dengan konvensional hampir mirip yaitu pada tahap adanya penyajian informasi atau presentasi guru. Yang membedakan 
hanya pada model pembelajaran STAD terdapat pemberian penghargaan terhadap kelompok. Menurut Sunilawati (2013), model pembelajaran kooperatif tipe STAD dalam implementasinya sangat memerlukan tekad, inovasi dan kesabaran guru dalam merancang pembelajaran sehingga peserta didik benar-benar menjadi tertarik untuk mengikuti pembelajaran. Sulinawati (2013) juga mengatakan hal yang menarik dari pembelajaran ini adalah adanya harapan selain memiliki dampak pembelajaran, yaitu berupa peningkatan hasil belajar peserta didik (student achievement) juga mempunyai dampak pengiring seperti keterampilan sosial.

Sistem reproduksi pada manusia merupakan suatu materi yang berkaitan dengan kelangsungan keberadaan manusia. Sistem reproduksi secara normal fungsinya tidak ditujukan pada homeostatis dan tidak penting bagi kelangsungan hidup individu, tetapi penting untuk kelangsungan hidup spesies (Sherwood, 2001). Reproduksi dilakukan secara seksual melalui peristiwa fertilisasi, yaitu peleburan antara sel sperma dengan sel ovum (Campbell, 2004). Sistem reproduksi manusia terdiri dari beberapa organ eksternal dan internal. Organ reproduksi pada wanita dan pria dirancang untuk terjadinya penyatuan bahan genetika dari hubungan seksual.

\section{METODE PENELITIAN}

Penelitian ini dilakukan pada bulan April-Juni 2017 di SMAN 102 Jakarta pada kelas XI semester II/genap tahun ajaran 2016/2017. Metode yang digunakan dalam penelitian ini adalah quasi eksperimen dengan Post-Test Only Control Group Design. Desain penelitian ini terdapat dua kelompok, yaitu kelompok satu sebagai kelas eksperimen dan kelompok dua sebagai kelas kontrol. Kelas eksperimen masing-masing diberikan perlakuan dengan pembelajaran Reciprocal Teaching dan PBL, serta kelas kontrol diberi perlakuan pembelajaran STAD terhadap kemampuan berpikir kritis peserta didik SMA.

\section{a. Sampel}

Sampel penelitian ini, yaitu berjumlah 99 peserta didik dari 108 peserta didik didapat dari rumus Slovin. Teknik 
pengambilan sampel dilakukan dengan menggunakan teknik simple random sampling. Pada penelitian ini, kelas XI MIA 1 yang berjumlah 36 peserta didik dan XI MIA 2 yang berjumlah 36 peserta didik sebagai kelas eksperimen yaitu menggunakan pembelajaran Reciprocal Teaching dan Problem Based Learning dan kelas XI MIA 3 yang berjumlah 36 peserta didik sebagai kelas kontrol menggunakan pembelajaran STAD

\section{b. Teknik Pengumpulan Data}

Pengumpulan data dilakukan dengan menggunakan daftar pertanyaan berupa instrumen tes hasil belajar kemampuan berpikir kritis peserta didik dan observasi. Jenis data yang diperoleh yaitu data utama yang diperoleh dari hasil test sedangkan untuk data pendukung akan diperoleh melalui hasil observasi. Data utama diperoleh dengan cara memberikan soal tes pada peserta didik dikelas eksperimen dan kelas kontrol yang dilaksanakan dengan memberikan post-test yang berupa soal pilihan ganda kemampuan berpikir kritis mengenai materi sistem reproduksi. Pemberian tes ini dilakukan setelah pertemuan kedua selesai. Data observasi dilakukan dengan menggunakan lembar observasi keterlaksaaan pembelajaran oleh guru dan lembar observasi aktivitas peserta didik.

\section{c. Hipotesis Statistik}

Perumusan hipotesis statistik pada penelitian ini adalah sebagai berikut:

$\mathrm{HO}$

$$
\begin{array}{ll}
\mathrm{H} 0 & : \mu \mathrm{x} 1=\mu \mathrm{x} 2=\mu \mathrm{xc} \\
\mathrm{H} 1 & : \mu \mathrm{x} 1 \neq \mu \mathrm{x} 2 \neq \mu \mathrm{xc}
\end{array}
$$

Keterangan:

$\mu x 1$ : Rata-rata kemampuan berpikir kritis peserta didik pada

materi sistem reproduksi dengan Pembelajaran Reciprocal Teaching 
$\mu \mathrm{x} 2$ : Rata-rata kemampuan berpikir kritis peserta didik pada materi sistem reproduksi dengan Pembelajaran Problem Based Learning

$\mu x c$ : Rata-rata kemampuan berpikir kritis peserta didik pada materi sistem reproduksi dengan Pembelajaran STAD

\section{HASIL DAN PEMBAHASAN}

Berdasarkan hasil nilai yang diperoleh melalui post-test kemampuan berpikir kritis pada materi sistem reproduksi pada tiga kelas berbeda yang masing-masing menerapkan Reciprocal Teaching (RT), Problem Based Learning (PBL), dan STAD sebagai kelas kontrol. Nilai rata-rata kemampuan berpikir kritis peserta didik pada kelas eksperimen lebih tinggi dari kelas kontrol. Pada kedua kelas eksperimen, rata-rata kemampuan berpikir kritis peserta didik kelas Reciprocal Teaching (RT) lebih tinggi daripada kelas Problem Based Learning (PBL).

Berdasarkan perhitungan post-test yang dilakukan pada kelas eksperimen yang menggunakan pembelajaran RT dan PBL dan kelas kontrol yang menggunakan STAD diperoleh hasil yaitu, rata-rata post-test pada kelas eksperimen RT sebesar 78,70, sedangkan kelas eksperimen PBL sebesar 75,67, dan kelas kontrol sebesar 73,36. Hal ini menunjukkan bahwa pada kelas eksperimen memiliki hasil rata-rata post-test kemampuan berpikir kritis yang lebih tinggi dibandingkan kelas kontrol.

Diantara kelas eksperimen, hasil rata-rata post-test kemampuan berpikir kritis materi sistem reproduksi kelas RT lebih tinggi daripada PBL. Perbedaan rata-rata post-test kemampuan berpikir kritis materi sistem reproduksi antara kelas eksperimen RT dan PBL, dan kelas kontrol dapat dilihat pada gambar 1 di bawah ini. 


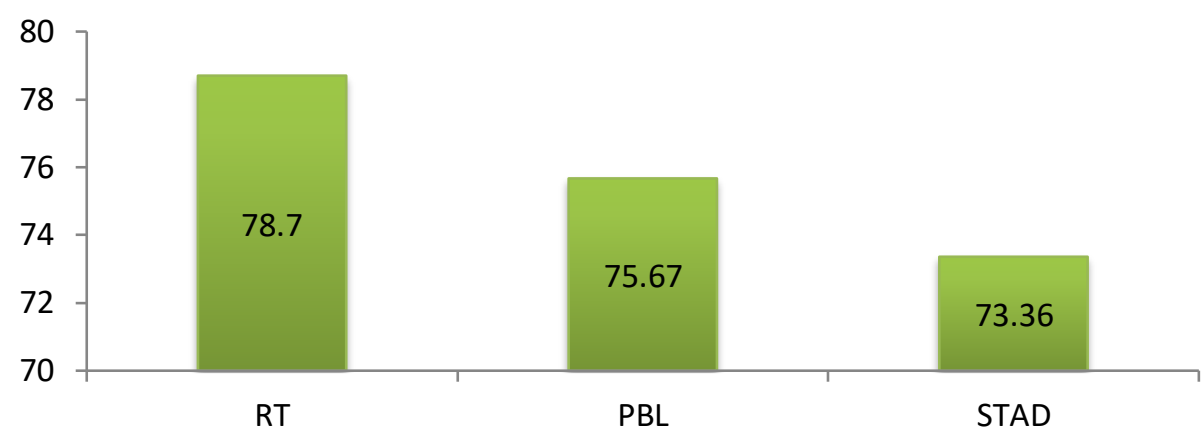

Gambar 1. Rata-rata Nilai Post-test Kemampuan Berpikir Kritis Materi Sistem Reproduksi pada Kelas Eksperimen dan Kontrol

\section{Hasil Pengujian Hipotesis}

Berdasarkan hasil perhitungan uji normalitas dan homogenitas dapat diketahui bahwa data berdistribusi normal dan homogen. Berdasarkan data tersebut maka dapat dilakukan uji hipotesis menggunakan uji ANAVA satu arah menggunakan aplikasi SPSS 22.0 pada taraf signifikansi $\alpha=0,05$ dengan hipotesis sebagai berikut: terima H0 bila nilai signifikansi lebih besar $\alpha=0,05$ dan tolak H0 bila nilai signifikansi lebih kecil dari $\alpha$ $=0,05$. Setelah didapat hasil perhitungan uji ANAVA satu arah dan kritis data, maka diperoleh nilai signifikansi kurang dari 0,05 yaitu $0,001<0,05$ maka tolak $\mathrm{H} 0$, artinya terdapat perbedaan rata-rata kemampuan berpikir kritis peserta didik.

Uji hipotesis dilanjutkan menggunakan uji Tuckey. Hasil uji Tuckey antara dua kelas eksperimen yaitu RT dan PBL terhadap kemampuan berpikir kritis peserta didik pada materi sistem reproduksi memiliki nilai signifikansi 0,06 > 0,05, maka terima Ho yang artinya tidak terdapat perbedaan rata-rata kemampuan berpikir kritis peserta didik.

\section{Pembahasan}

Terdapatnya perbedaan kemampuan berpikir kritis peserta didik antara kelas eksperimen RT dengan kelas kontrol STAD membuktikan bahwa adanya pengaruh dari model pembelajaran RT terhadap kemampuan berpikir kritis. Pengaruh yang didapatkan, yaitu model pembelajaran RT dapat 
meningkatkan kemampuan berpikir kritis peserta didik pada materi sistem reproduksi.

Hal ini didukung oleh beberapa penelitian sebelumnya mengenai pengaruh model pembelajaran Reciprocal Teaching terhadap kemampuan berpikir kritis, yaitu Sholihah (2016), dan Adiwijaya (2016), yang menyatakan bahwa RT mampu untuk meningkatkan kemampuan berpikir kritis peserta didik pada pembelajan biologi. Pembelajaran RT menekankan pada empat kegiatan utama dalam tahapan pembelajaran yaitu meringkas, membuat pertanyaan, memprediksi dan mengklasifikasikan. Hal ini sesuai dengan pernyataan Adiwijaya (2016), yang menyatakan bahwa pembelajaran RT merupakan pengajaran timbal balik yang aktif, terdapat interaksi antara peserta didik dengan peserta didik, peserta didik dengan guru dalam pemahaman bacaan untuk membangun pengetahuan peserta didik.

Kegiatan meringkas bacaan yang dilakukan oleh peserta didik dapat menggambarkan tingkat pemahaman peserta didik terhadap bacaan yang dibacanya. Dengan membaca, peserta didik belajar mengelola informasi yang didapat didasarkan pada data yang akurat. Mengelola informasi merupakan salah satu ciri berpikir kritis. Pernyataan tersebut didukung oleh peneltitian yang dilakukan oleh Zubaidah et al. (2008), yang menyatakan bahwa kegiatan meringkas dapat melatih peserta didik dalam menganalisis dan mengelola informasi berupa fakta dari bahan bacaan yang mereka baca. Selain itu, meringkas merupakan suatu proses berpikir kreatif dan kritis dalam mengolah informasiinformasi penting dalam sebuah bacaan.

Kegiatan selanjutnya dalam model pembelajaran RT yaitu membuat pertanyaan. Kegiatan membuat pertanyaan salah satu cara yang dilakukan untuk meningkatkan kemampuan berpikir kritis peserta didik. Pernyataan ini didukung oleh Zubaidah (2001), yang menyatakan bahwa peserta didik yang mengajukan pertanyaan merupakan peserta didik yang memiliki rasa ingin tahu yang tinggi. Hal ini juga didukung oleh Jacob dan San (2008), yang mengungkapkan bahwa membuat pertanyaan merupakan salah satu tahapan proses berpikir kritis dalam proses pemecahan masalah. Menurut Corebima (2008), bahwa pembelajaran dengan 
pemberdayaan berpikir melalui pertanyaan dapat digunakan untuk meningkatkan kemampuan berpikir kritis peserta didik.

Kegiatan berikutnya dalam penerapan model pembelajaran RT, yaitu membuat prediksi. Kegiatan membuat prediksi merupakan kegiatan penggabungan antara pengetahuan awal peserta didik dengan pengetahuan baru yang didapat peserta didik melalui bacaan yang mereka baca. Kegiatan selanjutnya yaitu, mengklarifikasi. Kegiatan mengklarifikasi merupakan salah satu tahapan proses berpikir kritis peserta didik dalam mengidentifikasi informasi penting dalam pemecahan masalah yang dihadapi. Ini merupakan kegiatan yang dapat membantu peserta didik yang kesulitan dalam memahami materi pembelajaran. Hal ini didukung oleh pernyataan Spivey (2006), yang menyatakan bahwa tahapan mengklarifikasi memberikan kesempatan peserta didik untuk belajar mandiri dan memahami kembali materi yang dirasa sulit.

Penerapan model pembelajaran Reciprocal Teaching diketahui dapat meningkatkan kemampuan berpikir kritis peserta didik dalam proses pembelajaran. Dengan meningkatnya kemampuan berpikir kritis peserta didik dalam belajar dapat diketahui bahwa peserta didik dapat memecahkan masalah dan mengelola informasi yang pada proses pembelajaran, sehingga dengan meningkatnya kemampuan berpikir kritis peserta didik dalam belajar akan meningkatkan kemampuan kognitif peserta didik dan dapat memecahkan masalah pada kehidupan seharihari. Hal tersebut sesuai dengan pernyataan Ramadani (dalam Nuur 2016), yang menyatakan bahwa kemampuan berpikir kritis dalam memecahkan masalah mampu menyiapkan peserta didik untuk menjalani karir dan kehidupan nyatanya. Hal ini juga didukung oleh penelitian Kusumaningtias (2013), yang mengungkapkan bahwa kemampuan berpikir kritis mempunyai manfaat kongkret dalam meningkatkan kemampuan kognitif.

Peserta didik yang memiliki kemampuan berpikir kritis cenderung menghasilkan prestasi belajar kognitif, afektif dan psikomotorik yang lebih baik. Hal ini sesuai dengan pendapat Nurlaila (2013), bahwa berpikir kritis memainkan peranan penting dalam membangun kognisi seseorang, hal ini karena berpikir kritis sebagian dari proses berpikir aktif. Oleh karena itu, 
seseorang yang memiliki kemampuan berpikir kritis apabila mengalami kesulitan dalam belajar akan berpikir cara menyelesaikan masalah tersebut berdasarkan fakta. Sehingga suatu keawajran jika peserta didik memilki kemampuan berpikir kritis dapat menghasilkan prestasi belajar yang tinggi pula.

Problem Based Learning merupakan pembelajaran yang diawali dengan ditandai dengan adanya masalah. Masalah yang digunakan berhubungan dengan masalah dunia nyata peserta didik, namun tetap berada pada konsep pembelajaran yang ditargetkan untuk dicapai peserta didik. Hal ini sesuai dengan pendapat Kusumaningtias (2013), bahwa PBL merupakan suatu pembelajaran yang menggunakan permasalahan secara kontekstual yang terjadi di dunia nyata. Pembelajaran PBL memberikan peluang kepada peserta didik untuk mengembangkan kemampuan berpikir kritis melalui proses pemecahan masalah yang kompleks yang disajikan. Hal ini didukung oleh penelitian Kusumaningtias (2013), yang mengatakan bahwa PBL merupakan pembelajaran yang dapat menggali kemampuan berpikir kritis dan kemampuan pemecahan masalah, serta melatih siswa menjadi pebelajar mandiri dan self regulated. Pembelajaran PBL memiliki ciri peserta didik bekerjasama dalam kelompok diskusi untuk bersama-sama memecahkan masalah yang disajikan oleh guru. Kelompok diskusi ini memungkinkan peserta didik untuk berdiskusi dan berhadapan dengan tingkat perbedaan pendapat yang tinggi dengan teman sekelompoknya (Manahal, 2007). Secara tidak langsung melalui diskusi dalam kelompok ini, peserta didik akan melatih dan mengembangkan keterampilan berpikir kritisnya.

Hal ini sesuai dengan penelitian Fakhriyah (2014), bahwa keadaan pembelajaran seperti diskusi akan membuat peserta didik melakukan analisis terhadap kebenaran dari pendapatpendapat yang ada, menjelaskakan hal-hal yang berhubungan dengan fakta dan memilih solusi terbaik dan memutuskan solusi terbaik untuk pemecahan permasalahan yang diberikan. Menganalisis pendapat yang ada merupakan salah satu proses menjadi pemikir kritis. Guru dalam pembelajaran PBL hanya berperan sebagai fasilitator, yang bertugas merencanakan kegiatan dan mendukung proses pembelajaran berlangsung. Hal 
ini sesuai dengan pendapat Walker \& Heather (2009), menyatakan bahwa dalam pembelajaran berbasis masalah, guru bertindak sebagai fasilitator dan membantu siswa dalam mengingatkan pengetahuan secara teoritis yang relevan dengan permasalahan yang ditemui, serta memimpin siswa dalam mengidentifikasi kesalahan pemahaman mereka sendiri. Pembelajaran PBL menuntut kesiapan guru yang harus berperan sebagai fasilitator dan pembimbing. Guru harus mengikuti kegiatan pembelajaran sesuai sintaks pembelajaran PBL agar proses pembelajaran berjalan secara efektif. Hal ini sesuai dengan pernyataan Rusman (2013), yang menyatakan guru dalam pembelajaran PBL dituntut dapat memahami secara utuh setiap bagian dan konsep PBl dan menjadi penengah yang mampu merangsang kemampuan berpikir peserta didik dan pembelajaran berjalan secara efektif.

Peserta didik akan terlibat penuh dalam pembelajaran dan bertindak sebagai subjek pembelajaran (student center). Keterlibatan peserta didik dalam pembelajaran PBL ini dapat membantu dalam mengembangkan kemampuan berpikir kritis, karena PBL melibatkan kemampuan peserta didik untuk mencari dan menyelidiki secara logis, kritis dan analitis sehingga mereka dapat merumuskan sendiri pemecahan masalah yang mereka dapat. Hal ini didukung oleh pendapat Saiful dan Aswan (2006), yang menyatakan bahwa kelebihan pembelajaran berbasis masalah adalah melatih peserta didik mendesain suatu penemuan, memecahkan masalah yang dihadapi secara realitis, dan melakukan penyelidikan serta merangsang kemajuan berpikir peserta didik untuk menyelesaikan masalah yang dihadapi dengan cepat.

STAD merupakan salah satu pembelajaran kooperatif yang menekankan pada belajar secara berkelompok dan dapat meningkatkan kemampuan berpikir kritis peserta didik melalui kegiatan diskusi kelompok. Sebagaimana yang diungkapkan oleh Nur (2013), bahwa pembelajaran kooperatif STAD ini berbentuk kelompok kerja sehingga menuntut siswa untuk aktif dalam pembelajaran secara berkelompok dikelas. Hal ini juga didukung oleh Ocker \& Yaverbaum (2004), bahwa pembelajaran dengan belajar kelompok dapat mengembangkan kemampuan berpikir 
kritis peserta didik dan pemecahan masalah. Menurut Zubaidah (2013), manfaat dari pembelajaran STAD antara lain: mampu meningkatkan kemampuan berpikir kritis, hasil belajar kognitif, keterampilan proses, pemahaman dan perolehan pengetahuan, kepedulian antar anggota kelompok, kemampuan pemecahan masalah, komunikasi dan kolaborasi peserta didik, serta menumbuhkan kesetikawanan sosial, kemampuan bekerja sama, memberikan pengaruh positif dalam mata pelajaran sosial, menarik minat belajar peserta didik, dan lain sebagainya. Hasil Belajar yang baik juga dipengaruhi oleh media pembelajaran, apabila media pembelajaran yang digunakan sesuai dengan karakteristik materi maka akan berdampak baik bagi peningkatan hasil belajar (Ichsan, Rusdi \& Sartono, 2017).

Berdasarkan hasil observasi keterlaksanaan pembelajaran oleh guru, keterlaksanaan pembelajaran pada kelas eksperimen dan kelas kontrol sudah memenuhi standar yang diinginkan. Menurut Riduwan (2009), kriteria rata-rata nilai keterlaksanaan pembelajaran oleh guru dan peserta didik pada kelas eksprimen dan kontrol memiliki kategori sangat baik, nilai rata-rata keterlaksanaan pembelajaran pada kategori ini memiliki rentang nilai sebesar 88,63-95,45\%.

\section{KESIMPULAN}

Berdasarkan hasil penelitian dan pengujian hipotesis dapat disimpulkan bahwa terdapat pengaruh pembelajaran Reciprocal Teaching (RT) dan Problem Based Learning (PBL) terhadap kemampuan berpikir kritis peserta didik SMA pada materi sistem reproduksi.

\section{DAFTAR PUSTAKA}

Abdullah, S. R. (2014). Pembelajaran Saintifik untuk Implementasi Kurikulum 2013. Jakarta: Bumi Aksara.

Adiwijaya, H., Suarsini, E., \& Lukiati, B. (2016). Penerapan Pembelajaran Reciprocal Teaching Berbantuan Peta Konsep Untuk Meningkatkan Kemampuan Berpikir Kritis Siswa 
pada Pembelajaran Biologi. Jurnal Pendidikan, 1 (12):23792387.

Afandi, Sugiyarto, Sunarno, \& Widha. (2012). Pembelajaran Biologi Menggunakan Pendekatan Metakognitif melalui Model Reciprocal Learning dan Problem Based Learning Ditinjau dari Kemandirian Belajar dan Kemampuan Berpikir Kritis Mahapeserta didik. Jurnal Inkuiri, 1(2):86-92.

Afcariono, M. (2008). Penerapan Pembelajaran Berbasis Masalah untuk Meningkatkan Kemampuan Berpikir Kritis Peserta didik pada Mata Pelajaran Biologi. Jurnal Pendidikan Inovatif, 3(2):13-14.

Amir, T. (2013). Inovasi Pendidikan Melalui Problem Based Learning. Jakarta: Kencana Prenada Media Grup.

Arends, R. I. (2008). Learning to Teach: Belajar untuk Mengajar. Yogyakarta: Pustaka Pelajar.

Campbell, N. A., Reece, J. B., dan Nitchel, L. G. (2004). Biologi: Edisi Kelima Jilid 3. Jakarta: Erlangga.

Corebima, A. D. (2008). Metacognitive Skill Measurement Integrated in Achievement Test. Malang: State University of Malang.

Doolittle, P. E., Hick, D. \& Triplett, C. F. (2006). Reciprocal Teaching for Reading Comprehension in Higher Education: A Strategy for Fostering the Deeper Understanding of Texts. International Journal of Teaching and Learning in Higher Education, 17(2):106-118.

Ennis, R. H et al. (1996). Critical Thinking. USA: Prentice Hall, Inc.

Fakhriyah, F. (2014). Penerapan Problem Based Learning dalam Upaya Mengembangkan Kemampuan Berpikir Kritis Mahasiswa. Jurnal Pendidikan IPA Indonesia. 3(1): 95-101. 
Fisher, A. (2009). Berpikir Kritis: Sebuah Pengantar. Jakarta: Erlangga.

Hasruddin. (2009). Memaksimalkan Kemampuan Berpikir Kritis Melalui Pendekatan Kontekstual. Jurnal Tabularasa PPS Unimed, 6(1):48-60.

Ichsan, I. Z., Rusdi, R., \& Sartono, N. (2017). Hasil Belajar Sistem Saraf Menggunakan Film Pendek. Biosfer: Jurnal Pendidikan Biologi, 10(2), 49-59.

Ibnu, T. B. A. (2014). Mendesain Model Pembelajaran Innovatif, Progresif, dan Kontekstual: Konsep, Landasan, dan Implementasinya pada Kurikulum 2013. Jakarta: Kencana.

Ibrahim, M. (2008). Pengajaran Berdasarkan Masalah. Surabaya: UNESA University Press.

Isjoni. (2009). Cooperative Learning Efektifitas Learning Efektifitas Pembelajaran Kelompok, Bandung: Alfabets.

Jacob, S. M \& Sam, H. K. (2008). Measuring Critical Thinking in Problem Solving Through Online Discussion Forums in First Year University Mathematics. Proceedings of the International MultiConference of Engineers and Computer Scientists 2008, 1(3):32-36.

Kusumaningtias, A., Zubaidah, S., \& Endah, S. I (2013). Pengaruh Problem Based Learning Dipadu Strategi Numbered Heads Together terhadap Kemampuan Metakognitif, Berpikir Kritis, dan Kognitif Biologi. Jurnal Penelitian Kependidikan. 23(1): 33-42.

Mahanal, S., Pujiningrum, S. E., \& Suyanto. (2007). Penerapan Pembelajaran Berdasarkan Masalah dengan Strategi Kooperatif Model STAD pada Mata Pelajaran Sains untuk Meningkatkan Kemampuan Berpikir Kritis Siswa Kelas V MI 
Jenderal SudirmanMalang. Jurnal Penelitian Kependidikan, 1(19):234-252.

Majid, A. (2013). Strategi Pembelajaran. Bandung: PT Remja Rosdakarya.

Masek, A \& Sulaiman, Y. (2011). The Effect of Problem Based Learning on Critical Thingking Ability: A Theoretical and Emprical Review. Jurnal International Review of Social Sciences and Humanities. 2(1): 225-221.

Moore, B. N. and Parker, R. (2009). Critical Thinking. New York: McGraw-Hill Co. Inc.

Nurlaila, N., Suparmi, \& Sunarno, W. (2013). Pembelajaran Fisika dengan PBL menggunakan Problem Solving dan Problem Posing Ditinjau dari Kreativitas dan Keterampilan Berpikir Kritis Siswa. Jurnal Inkuiri. 2(2): 114-123.

Nuur, P. M., Mahana, S., \& Suwono, H. (2016). Keterampilan Berpikir Kritis pada Pembelajaran Biologi Siswa Kelas X SMA. Prosiding Seminar Nasional II.

Pusat Bahasa Departemen Pendidikan Nasional. (2005). Kamus Besar Bahasa Indonesia. Jakarta: Balai pustaka.

Riduwan, S. (2009). Pengantar Statistik: Untuk Penelitian Pendidikan, Sosial, Ekonomi, Komunikasi, dan Bisnis. Jakarta: Bumi Aksara.

Rusman. (2012). Model-model Pembelajaran: Mengembangkan Profesionalisme Guru. Jakarta: Rajawali Pers.

Saiful, B \& Aswan, Z. (2006). Strategi Belajar Mengajar. Jakarta: PT Rineka Cipta

Santrock, J. W. (2008). Psikologi Pendidkan. Jakarta: Prenada Media Group. 
Anggraeni, H. et al.,

Sherwood, L. (2001). Fisiologi Manusia; dari Sel ke Sistem. Jakarta: EGC.

Sholihah, M., Zubaidah, S., \& Mahanal, S. (2016). REMAP RT (Reading Concept Map Reciprocal Teaching) untuk Meningkatkan Keterampilan Berpikir Kritis Siswa. Proceeding Biology Education Conference, 13(1): 280-284.

Spivey, N. R., Cuthbert, A. (2006). Reciprocal Teaching of Lecture Comprehension Skills in College Students. Journal of Scholarship of Teaching and Learning, 6 (2):66-83.

Sudarman. (2007). Problem Based Learning: Suatu Model Pembelajaran untuk Mengembangkan dan Meningkatkan Kemampuan Memecahkan Masalah. Jurnal Pendidian Inovatif, 2(2): 68-73.

Sunilawati, N. M., Dantes, N., \& Candiasa, I. M. (2013). Pengaruh Model Pembelajaran Kooperatif Tipe STAD Terhadap Hasil Belajar Matematika Ditinjau Dari Kemampuan Numerik Peserta didik Kelas IV SD. e-Journal Program Pascasarjana Universitas Pendidikan Ganesha Jurusan Guruan Dasar, 3(5):43-47.

Suyadi. (2013). Strategi Pembelajaran Pendidikan Karakter. Bandung: PT Remaja Rosdakarya

Suyitno, A. (2004). Dasar-dasar dan Proses Pembelajaran Matematika I. Semarang: FMIPA UNNES.

Walker, A., \& Heatler, L. (2009). A Problem Based Learning Meta Analysis: Differences Across Problem Types, Implementation Types, Disciplines, and Assessment Levels. The Inerdisciplinary Journal of Problem-based Learning, 3(1): 12-43. 
Wicaksono, A. G. \& Candra. (2014). Hubungan Keterampilan Metakognitif dan Berpikir Kritis terhadap Hasil Belajar Kognitif Peserta didik SMA pada Pembelajaran Biologi dengan Strategi Reciprocal Teaching. Jurnal Pendidikan Sains, 2(2):85-92.

Zubaidah, S. (2001). Beberapa Alternatif Pembelajaran untuk Meningkatkan Pemahaman terhadap Istilah atau Konsep Biologi. Sumber Belajar, Kajian Teori dan Aplikasi. 1(8):3651.

Zubaidah, S. (2013). Pemberdayaan Keterampilan Penemuan dalam Scientific Approach melalui Pembelajaran Berbasis Remap Coople. Prosiding Seminar Nasional XI bertema Biologi, Sains, Lingkungan dan Pembelajaran di Universitas Sebelas Maret. Hal 1000-1011.

Zubaidah, S., Chasanah, U. \& Chairuddin. (2008). Penerapan Metode Inkuiri dan Reciprocal Teaching untuk Meningkatkan Kemampuan Berpikir Siswa Kelas V MI Wahid Hasyim III Malang. Jurnal Sekolah Dasar, Kajian Teori, dan Praktik Pendidikan, 2(17): 232-247. 